\title{
Synthesis and Crystal Structure of Chalcogenide Cluster Compound
}

\author{
Bárbara Tirloni, ${ }^{a}$ Davi F. Back, ${ }^{a}$ Robert A. Burrow, ${ }^{a}$ Gelson N. M. de Oliveira, ${ }^{a}$ \\ Marcos A. Villetti ${ }^{b}$ and Ernesto S. Lang $*, a$ \\ ${ }^{a}$ Departamento de Química, Universidade Federal de Santa Maria, \\ 97105-900, Santa Maria-RS, Brazil \\ ${ }^{b}$ Departamento de Física, Universidade Federal de Santa Maria, \\ 97105-900, Santa Maria-RS, Brazil
}

\begin{abstract}
Três novos compostos foram preparados a partir de $\mathrm{Hg}(\mathrm{EPh})_{2}(\mathrm{E}=\mathrm{Se}, \mathrm{Te} ; \mathrm{Ph}=$ fenila $)$ em solventes orgânicos. Dois destes compostos são clusters moleculares, $\left[\mathrm{Hg}_{2} \mathrm{Cl}_{2}(\mathrm{SePh})_{2}\left(\mathrm{PCy}_{3}\right)_{2}\right]$, (1), e $\left[\mathrm{Hg}_{2} \mathrm{Br}_{2}(\mathrm{SePh})_{2}\left(\mathrm{PCy}_{3}\right)_{2}\right]$, (2), obtidos pela reação de $\mathrm{Hg}(\mathrm{SePh})_{2}$ com $\mathrm{HgX}_{2}(\mathrm{X}=\mathrm{Cl}$, $\mathrm{Br})$ e tricicloexilfosfina, $\mathrm{PCy}_{3}$, em dimetilformamida. A reação de $\mathrm{Hg}(\mathrm{TePh})_{2}$ e $\mathrm{HgBr}{ }_{2}$ em tetrahidrofurano usando trifenilfosfina ou 2,2'-bipiridina como co-ligantes produz o cluster polimérico $\left[\left\{\mathrm{Hg}_{5} \mathrm{Br}_{3}(\mathrm{TePh})_{7}\right\}_{n}\right],(\mathbf{3})$, cuja dissolução em dimetilsulfóxido leva à formação do cluster $\left[\mathrm{Hg}_{3} \mathrm{Br}_{3}(\mathrm{TePh})_{3}\right] \cdot 2 \mathrm{dmso}$. Neste trabalho avalia-se a influência de diferentes ligantes, solventes coordenantes e estequiometrias de reações na formação dos produtos. Todos os compostos foram caracterizados por análise elementar, análise termogravimétrica e tiveram suas estruturas cristalinas determinadas por difratometria de raios $\mathrm{X}$ em monocristais.
\end{abstract}

\begin{abstract}
Three new cluster compounds were synthesized from $\mathrm{Hg}(\mathrm{EPh})_{2}(\mathrm{E}=\mathrm{Se}, \mathrm{Te} ; \mathrm{Ph}=$ phenyl $)$ in organic solvents. Two of these compounds, $\left[\mathrm{Hg}_{2} \mathrm{Cl}_{2}(\mathrm{SePh})_{2}\left(\mathrm{PCy}_{3}\right)_{2}\right],(\mathbf{1})$, and $\left[\mathrm{Hg}_{2} \mathrm{Br}_{2}(\mathrm{SePh})_{2}\left(\mathrm{PCy}_{3}\right)_{2}\right]$, (2), were prepared by reaction of $\mathrm{Hg}(\mathrm{SePh})_{2}, \mathrm{HgX}_{2}(\mathrm{X}=\mathrm{Cl}, \mathrm{Br})$ and tricyclohexylphosphine, $\mathrm{PCy}_{3}$, in dimethylformamide. The reaction of $\mathrm{Hg}(\mathrm{TePh})_{2}$ with $\mathrm{HgBr}_{2}$ in tetrahydrofuran using triphenylphosphine or 2,2'-bipyridine as co-ligands gave the polymeric cluster $\left[\left\{\mathrm{Hg}_{5} \mathrm{Br}_{3}(\mathrm{TePh})_{7}\right\}_{n}\right](\mathbf{3})$, whose dissolution in dimethylsulfoxide yielded the cluster $\left[\mathrm{Hg}_{3} \mathrm{Br}_{3}(\mathrm{TePh})_{3}\right] \cdot 2 \mathrm{dmso}$. The influence of different ligands, coordinating solvents and reaction stoichiometries on the formation of the title compounds is also discussed. All complexes were characterized by elemental analysis, thermogravimetric analysis and single crystal X-ray diffractometry.
\end{abstract}

Keywords: mercury(II) complexes, selenium, tellurium, clusters

\section{Introduction}

The search for new metalchalcogen-containing building blocks is of great interest for many reasons, principally because the controllable size of the blocks produces tunable optoeletronic properties of the bulk products, ${ }^{1,2}$ but also due to other new materials and biological applications. ${ }^{3}$ This emerging field - super lattices of crystalline chalcogenides links two traditional, but distinct, areas of research: chalcogenide clusters and porous materials. ${ }^{4-8}$

Chalcogenide cluster compounds with mercury are still quite rare, even though these materials possess interesting properties as bulk- or nano-materials. The alloy $\mathrm{Cd}_{1-\mathrm{x}} \mathrm{Hg}_{\mathrm{x}} \mathrm{Te}$,

*e-mail: eslang@quimica.ufsm.br for example, is a well known material in long-wavelength IR detector technologies, and HgTe nanoparticles have been proposed as potential amplifiers in telecommunication devices. $^{9-12}$

Some authors have proposed alternative ways to increase the research on metal-chalcogenide clusters. Steigerwald and co-workers ${ }^{13-16}$ have demonstrated the utility of trialkylphosphine tellurides $\left(\mathrm{R}_{3} \mathrm{P}=\mathrm{Te}\right)$ as a source of soluble "tellurium( $(0)$ " to form numerous metaltelluride polynuclear complexes. Corrigan ${ }^{17}$ and Fenske ${ }^{18-20}$ have introduced condensation reactions of phosphinestabilized copper-tellurolate clusters for the generation of higher nuclearity complexes, ${ }^{17}$ as well as the use of arylselenolate ligands to stabilize copper-selenide and silver-selenide clusters. ${ }^{18-20}$ Mercury selenide and telluride 
cluster compounds and their conversion have been studied recently by Eichhöfer and Deglmann ${ }^{12}$ and previously by other authors, ${ }^{13-21}$ in order to extend optical investigation on IIb-VI cluster molecules.

Given our interest in the organochalcogenide chemistry, we have investigated the reactions of $\mathrm{M}(\mathrm{EPh})_{2}$ with $\mathrm{MX}_{2}$ $(\mathrm{M}=\mathrm{Hg}, \mathrm{Cd} ; \mathrm{E}=\mathrm{Se}, \mathrm{Te} ; \mathrm{X}=\mathrm{Cl}, \mathrm{Br}, \mathrm{I})$ in coordinating solvents. ${ }^{22,23}$ We have already reported results about the influence of ligands, coordinating solvents and reaction stoichiometry on the size and stereochemistry of different cluster compounds. ${ }^{24-30}$ In a recent communication we described the reactions of $\mathrm{Hg}(\mathrm{TePh})_{2}$ with $\mathrm{M}^{\prime}$-salts $\left(\mathrm{M}^{\prime}=\mathrm{Ag}^{\mathrm{I}}\right.$, $\left.\mathrm{Co}^{\mathrm{II}}, \mathrm{Ni}^{\mathrm{II}}\right)$, stabilized by phosphines $\left(\mathrm{PPh}_{3}\right.$ or $\left.\mathrm{P}\left(\mathrm{CH}_{3}\right)_{2} \mathrm{Ph}\right)$ and pyridine. ${ }^{31-33}$ These papers discuss new synthetic routes to achieve either binary as ternary cluster compounds.

Finally, we have found out that a critical step to develop new clusters under controlled conditions is the adequate understanding of the processes which lead to the stabilization and isolation of species like $\mathrm{PhEHgX}$ $(\mathrm{E}=\mathrm{Se}, \mathrm{Te} ; \mathrm{X}=\mathrm{Cl}, \mathrm{Br})$. In order to demonstrate these procedures and to extend the applicability of this methodology to further examples, we describe the preparation and the structural characterization of the two cluster molecules $\left[\mathrm{Hg}_{2} \mathrm{Cl}_{2}(\mathrm{SePh})_{2}\left(\mathrm{PCy}_{3}\right)_{2}\right],(\mathbf{1})$, and $\left[\mathrm{Hg}_{2} \mathrm{Br}_{2}(\mathrm{SePh})_{2}(\mathrm{PCy})_{2}\right],(\mathbf{2})$, as well as of the polymeric cluster $\left[\left\{\mathrm{Hg}_{5} \mathrm{Br}_{3}(\mathrm{TePh})_{7}\right\}_{n}\right](\mathbf{3})$.

\section{Experimental}

\section{Materials and measurements}

$\mathrm{HgCl}_{2}$ and $\mathrm{HgBr}_{2}$ and other analytical grade reagents and solvents were obtained commercially (Aldrich or Sigma) and used without further purification. Elemental analyses $(\mathrm{CHN})$ were attained with a Perkin-Elmer 2400 analyzer. A Bruker CCD X8 APEX II diffractometer was used for the X-ray structure analyses. The equipment was operated using graphite monochromator and $\mathrm{Mo}-\mathrm{K}_{\alpha}$ radiation $(\lambda=0.71073 \AA)$.

\section{Crystal structure determinations}

Colorless crystals of the compounds $\mathbf{1}, \mathbf{2}$ and $\mathbf{3}$ were obtained from their solutions at room temperature. The structures were solved with SHELXS by direct methods. ${ }^{34}$ All non-hydrogen atoms were refined with anisotropic displacement parameters with SHELXL. ${ }^{34}$ Hydrogen atoms were placed at their theoretical ideal positions. More detailed information about the structure determinations is given in Table 1.

\section{Thermogravimetric analyses}

Thermogravimetric measurements were carried out on a Shimadzu DTG-60 thermogravimetric analyzer. The experiments were performed in the temperature range from 25 to $700{ }^{\circ} \mathrm{C}$ with a heating rate of $10{ }^{\circ} \mathrm{C} \mathrm{min}-1$ for each sample. The average sample size was $10 \mathrm{mg}$ and the nitrogen flow-rate was $50 \mathrm{~mL} \mathrm{~min}^{-1}$.

Preparation of $\left[\mathrm{Hg}_{2} \mathrm{Cl}_{2}(\mathrm{SePh})_{2}\left(\mathrm{PCy}_{3}\right)_{2}\right],(\mathbf{1})$

To a solution of $0.051 \mathrm{~g}(0.1 \mathrm{mmol})$ of $\mathrm{Hg}(\mathrm{SePh})_{2}$ in $5 \mathrm{~mL}$ of dmf (dimethylformamide), $0.027 \mathrm{~g}(0.1 \mathrm{mmol})$ of $\mathrm{HgCl}_{2}$ was added and the mixture was stirred for $10 \mathrm{~min}$. Tricyclohexylphosphine $(0.056 \mathrm{~g}, 0.2 \mathrm{mmol})$ was also added and after $4 \mathrm{~h}$ stirring under Ar atmosphere, a light yellow solution was obtained. After 5 days, colorless crystals suitable for X-ray analysis had formed. Yield: $0.106 \mathrm{~g}, 79 \%$ based on $\mathrm{Hg}(\mathrm{SePh})_{2}$. Colorless crystalline substance. Elemental analysis for compound $\mathbf{1}$ (Found: C, 42.79; H, 5.59. Calc. for $\mathrm{C}_{48} \mathrm{H}_{76} \mathrm{Cl}_{2} \mathrm{Hg}_{2} \mathrm{P}_{2} \mathrm{Se}_{2}$ : C, 42.86; $\mathrm{H}, 5.70 \%)$.

\section{Preparation of $\left.\left[\mathrm{Hg}_{2} \mathrm{Br}_{2}(\mathrm{SePh})_{2}(\mathrm{PCy})_{3}\right)_{2}\right]$, (2)}

To a solution of $0.051 \mathrm{~g}(0.1 \mathrm{mmol})$ of $\mathrm{Hg}(\mathrm{SePh})_{2}$ in $5 \mathrm{~mL}$ of dmf, $0.036 \mathrm{~g}$ ( $0.1 \mathrm{mmol})$ of $\mathrm{HgBr}_{2}$ was added and the mixture was stirred for $10 \mathrm{~min}$. Thereafter $0.056 \mathrm{~g}$ $(0.2 \mathrm{mmol})$ of tricyclohexylphosphine was also added and, after $4 \mathrm{~h}$ stirring under Ar atmosphere, a light yellow solution was obtained. After 7 days colorless crystals suitable for X-ray analysis were formed. Yield: $0.117 \mathrm{~g}, 82 \%$ based on $\mathrm{Hg}(\mathrm{SePh})_{2}$. Colorless crystalline substance. Elemental analysis for compound 2 (Found: C, 40.27; H, 5.16. Calc. for $\mathrm{C}_{48} \mathrm{H}_{76} \mathrm{Br}_{2} \mathrm{Hg}_{2} \mathrm{P}_{2} \mathrm{Se}_{2}$ : C, 40.20; $\mathrm{H}, 5.34 \%)$.

\section{Preparation of $\left[\left\{\mathrm{Hg}_{5} \mathrm{Br} r_{3}(\mathrm{TePh})_{7}\right\}_{n}\right],(3)$}

A mixture of $0.213 \mathrm{~g}(0.35 \mathrm{mmol})$ of $\mathrm{Hg}(\mathrm{TePh})_{2}$, $0.054 \mathrm{~g}(0.15 \mathrm{mmol})$ of $\mathrm{HgBr}_{2}$ and $0.078 \mathrm{~g}(0.3 \mathrm{mmol})$ of $\mathrm{PPh}_{3}$ or 2,2 '-bipyridine $(0.032 \mathrm{~g}, 0.2 \mathrm{mmol})$, was suspended in $15 \mathrm{~mL}$ tetrahydrofuran and stirred for $1 \mathrm{~h}$ at $65{ }^{\circ} \mathrm{C}$. During the reaction the yellow suspension turned orange. The solid was removed by filtration, and after 7 days the solution yielded colorless crystals suitable for X-ray analysis. Yield: $0.109 \mathrm{~g}, 41 \%$ based on $\mathrm{Hg}(\mathrm{TePh})_{2}$. Colorless crystalline substance. Elemental analysis for compound $\mathbf{3}$ (Found: C, 19.02; H, 1.35. Calc. for $\mathrm{C}_{42} \mathrm{H}_{35} \mathrm{Br}_{3} \mathrm{Hg}_{5} \mathrm{Te}_{7}: \mathrm{C}, 18.87 ; \mathrm{H}, 1.31 \%$ ). 


\section{Results and Discussion}

\section{Syntheses of the compounds}

The reaction of $\mathrm{Hg}(\mathrm{EPh})_{2}(\mathrm{E}=\mathrm{Se}, \mathrm{Te})$ with $\mathrm{HgX}_{2}$ $(\mathrm{X}=\mathrm{Cl}, \mathrm{Br})$ and $\mathrm{PR}_{3}(\mathrm{R}=$ alkyl, aryl $)$ in coordinating solvents leads, according to Scheme 1, to the formation of $\left[\mathrm{Hg}_{2} \mathrm{Cl}_{2}(\mathrm{SePh})_{2}\left(\mathrm{PCy}_{3}\right)_{2}\right],(\mathbf{1}),\left[\mathrm{Hg}_{2} \mathrm{Br}_{2}(\mathrm{SePh})_{2}\left(\mathrm{PCy}_{3}\right)_{2}\right],(\mathbf{2})$, and $\left[\left\{\mathrm{Hg}_{5} \mathrm{Br}_{3}(\mathrm{TePh})_{7}\right\}_{n}\right],(\mathbf{3})$. Experimental evidence based on our previous results (see compounds 4-17 in Scheme 1) allows us to propose that $\mathrm{Hg}(\mathrm{EPh})_{2}$ exists according to the redistribution equilibrium shown in equation $1 .{ }^{24-30}$

$$
\mathrm{Hg}(\mathrm{EPh})_{2}+\mathrm{HgX}_{2} \leftrightharpoons 2[\mathrm{HgX}(\mathrm{EPh})](\mathbf{A})
$$

For the syntheses of $\mathbf{1}$ and $\mathbf{2}$ through one-pot procedures, the initial reaction represented in equation 1 , with the formation of the intermediary $[\mathrm{HgX}(\mathrm{EPh})]$, must be quantitative.

$$
\left[\mathrm{Hg}_{2} \mathrm{X}_{2}(\mathrm{SePh})_{2}\left(\mathrm{PCy}_{3}\right)_{2}\right] \quad \mathrm{X}=\mathrm{Cl}(\mathbf{1}) ; \operatorname{Br}(\mathbf{2})
$$

$$
\left\{\begin{array}{l}
\mathrm{HgX}_{2} \\
\mathrm{PCy}_{3} \\
\mathrm{dmf}
\end{array}\right.
$$

\begin{tabular}{|c|c|}
\hline $\mathrm{HgX}_{2}$ & {$\left[\left\{\mathrm{Hg}_{5} \mathrm{Br}_{3}(\mathrm{TePh})_{7}\right\}_{\mathrm{n}}\right]$ (3) } \\
\hline $\mathrm{PPh}_{3}+\mathrm{dmf}$ & {$\left[\left\{\mathrm{Hg}_{5} \mathrm{Cl}_{3}(\mathrm{SePh})_{7}\right\}_{n}\right](\mathbf{4})^{24}$} \\
\hline
\end{tabular}

$\mathrm{Hg}(\mathrm{EPh})_{2}$

$(\mathrm{E}=\mathrm{Se}, \mathrm{Te})$

$$
\begin{aligned}
& {\left[\mathrm{Hg}_{3} \mathrm{X}_{3}(\mathrm{TePh})_{3}\right] \cdot 2 \mathrm{dmso}(\mathrm{X}=\mathrm{Cl}, \mathrm{Br}, \mathrm{I})(\mathbf{5 - 7})^{25}} \\
& {\left[\mathrm{Hg}_{3} \mathrm{Br}_{3}(\mathrm{SePh})_{3}\right] \cdot 2 \mathrm{dmso}(\mathbf{8})^{26}} \\
& {\left[\left\{\mathrm{Hg}_{4} \mathrm{X}(\mathrm{SePh})_{7} \mathrm{py}\right\}_{n}\right](\mathrm{X}=\mathrm{Br}, \mathrm{Cl})(\mathbf{9 - 1 0})^{27,28}} \\
& {\left[\left\{\mathrm{Hg}_{4} \mathrm{I}(\mathrm{SePh})_{7}(\mathrm{dmf})\right\}_{n}\right](\mathbf{1 1})^{28}} \\
& {\left[\mathrm{Hg}_{5} \mathrm{Cl}_{4}(\mathrm{TePh})_{6}(\mathrm{PPh})_{2}\right](\mathbf{1 2})^{29}} \\
& {\left[\mathrm{Hg}_{6} \mathrm{X}_{4}(\mathrm{TePh})_{8}(\mathrm{py})_{2}\right](\mathrm{X}=\mathrm{Br}, \mathrm{Cl})(\mathbf{1 3 - 1 4})^{25,29}} \\
& {\left[\left\{\mathrm{Hg}_{7} \mathrm{X}_{3}(\mathrm{SePh})_{11}\right\}_{n}\right](\mathrm{X}=\mathrm{Cl}, \mathrm{Br})(\mathbf{1 5 - 1 6})^{24}} \\
& {\left[\left\{\mathrm{Hg}_{8} \mathrm{Br}_{4}(\mathrm{Te}-\mathrm{n}-\mathrm{propyl})_{12}\right\}_{\mathrm{n}}\right](\mathbf{1 7})^{30}}
\end{aligned}
$$

Scheme 1.

Stabilization of the intermediary $[\mathrm{HgX}(\mathrm{EPh})]$ in presence of a coordinative solvent $\left(\mathrm{L}_{1}\right)$ and a potential ligand $\left(\mathrm{L}_{2}\right)$ could generate a new species according to equation 2, which would further condense to form the final products with loss of $\mathrm{L}_{1}$ to give the correct $\mathrm{Hg} / \mathrm{X} / \mathrm{EPh} / \mathrm{L}_{2}$ stoichiometry.

$$
[\mathrm{HgX}(\mathrm{EPh})]+\mathrm{L}_{1}+\mathrm{L}_{2} \rightarrow\left[\mathrm{HgX}(\mathrm{EPh})\left(\mathrm{L}_{1}\right)\left(\mathrm{L}_{2}\right)\right](\mathbf{B})
$$

In the case of the formation of $\mathbf{1}$ and $\mathbf{2}$, the strongly polar dimethylformamide solvent and tricyclohexylphosphine

(a strong Lewis $\sigma$ base and good Lewis $\pi$-acid) will both coordinate to the $\mathrm{Hg}$ center in the intermediary $[\mathrm{HgX}(\mathrm{SePh})], \mathbf{A}$, to form a species like $[\mathrm{HgX}(\mathrm{SePh})(\mathrm{dmf})$ $\left(\mathrm{PCy}_{3}\right)$ ], B. Stoichiometrically, the final reaction for the formation of the solvated monomeric species $[\mathrm{HgX}(\mathrm{EPh})$ $\left.(\mathrm{dmf})\left(\mathrm{PCy}_{3}\right)\right]$ should be:

$$
\begin{aligned}
\mathrm{Hg}(\mathrm{SePh})_{2}+\mathrm{HgX}_{2}+2 & \mathrm{PCy}_{3}+2 \mathrm{dmf} \rightarrow \\
& \rightarrow 2\left[\mathrm{HgX}(\mathrm{SePh})(\mathrm{dmf})\left(\mathrm{PCy}_{3}\right)\right]
\end{aligned}
$$

Condensation of the proposed solvated $\mathrm{Hg}$ species $\left[\mathrm{HgX}(\mathrm{SePh})(\mathrm{dmf})\left(\mathrm{PCy}_{3}\right)\right]$ with concomitant loss of the solvent will produce the dimeric clusters $\mathbf{1}$ and $\mathbf{2}$. Experimentally, we have proven that if an additional equivalent of tricyclohexylphosphine is used, the condensation process can be blocked and only $\left[\mathrm{HgX}_{2}\left(\mathrm{PCy}_{3}\right)_{2}\right]$ is isolated and identified.

For the formation of $\mathbf{3}$ in a one-pot procedure, the final reaction follows the stoichiometric ratio presented in equation 4.

$$
3.5 \mathrm{Hg}(\mathrm{TePh})_{2}+1.5 \mathrm{HgBr}_{2} \rightarrow\left[\left\{\mathrm{Hg}_{5} \mathrm{Br}_{3}(\mathrm{TePh})_{7}\right\}_{n}\right]
$$

In this case, the less polar solvent thf, together with triphenylphosphine (or 2,2'-bipyridine), should form the intermediary B. In the presence of $[\mathrm{HgBr}(\mathrm{TePh})]$, both ligands $\mathrm{L}_{1}$ and $\mathrm{L}_{2}$ in $\mathbf{B}$ are displaced to give the more stable cluster $\left[\left\{\mathrm{Hg}_{5} \mathrm{Br}_{3}(\mathrm{TePh})_{7}\right\}_{n}\right]$. The new polymeric cluster $\mathbf{3}$ is formed with the displacement of $\mathrm{L}_{1}$ and $\mathrm{L}_{2}$, because the higher number of $\mathrm{Hg}-\mathrm{Te}$ and $\mathrm{Hg}-\mathrm{Br}$ bonds is preferred to the weaker $\mathrm{Hg}-\mathrm{P}$ or $\mathrm{Hg}-\mathrm{N}$ bonds of the displaced co-ligands. If more polar solvents like dimethylsulfoxide (dmso) or pyridine (py) in similar conditions are used, the compounds $\left[\mathrm{Hg}_{3} \mathrm{Br}_{3}(\mathrm{TePh})_{3}\right] \cdot 2 \mathrm{dmso},(6)$, and $\left[\mathrm{Hg}_{6} \mathrm{Br}_{4}(\mathrm{TePh})_{8}(\mathrm{py})_{2}\right]$, (13), are obtained. ${ }^{25}$ When the cluster 3 was re-dissolved in dmso, only the cluster 6 could be isolated. These results suggest that a dynamic process involving the coordination and loss of the solvent is present.

\section{Crystal structure of the cluster compounds}

The X-ray crystal data and the experimental conditions for the analyses of the clusters $\left[\mathrm{Hg}_{2} \mathrm{Cl}_{2}(\mathrm{SePh})_{2}\left(\mathrm{PCy}_{3}\right)_{2}\right]$, (1), $\left[\mathrm{Hg}_{2} \mathrm{Br}_{2}(\mathrm{SePh})_{2}\left(\mathrm{PCy}_{3}\right)_{2}\right],(\mathbf{2})$, and $\left[\mathrm{Hg}_{5} \mathrm{Br}_{3}(\mathrm{TePh})_{7}\right],(\mathbf{3})$, are given in Table 1. Tables 2 and 3 present selected bond distances and angles for the title compounds. Figures 1, 2 and 3 show the ORTEP drawing of compounds 1, 2 and $\mathbf{3}$, respectively. Figure 4 displays the polymeric assembly of 3 along the crystallographic axis $a$.

Figures 1 and 2 show the molecular structures of two asymmetric units of $\mathbf{1}$ and $\mathbf{2}$ linked through halogen bridges. 
Table 1. Crystal data, data collection procedure, structure determination and refinement for complexes 1-3

\begin{tabular}{|c|c|c|c|}
\hline & 1 & 2 & 3 \\
\hline Empirical formula & $\mathrm{C}_{48} \mathrm{H}_{76} \mathrm{Cl}_{2} \mathrm{P}_{2} \mathrm{Se}_{2} \mathrm{Hg}_{2}$ & $\mathrm{C}_{48} \mathrm{H}_{76} \mathrm{Br}_{2} \mathrm{P}_{2} \mathrm{Se}_{2} \mathrm{Hg}_{2}$ & $\mathrm{C}_{42} \mathrm{H}_{35} \mathrm{Br}_{3} \mathrm{Te}_{7} \mathrm{Hg}_{5}$ \\
\hline Formula weight, $\mathrm{M}$ & 1345.03 & 1433.95 & 2675.58 \\
\hline Temperature, T (K) & 293(2) & 293(2) & 293(2) \\
\hline Wavelength $(\mathrm{pm}) /$ radiation & $0.71073 / \mathrm{MoK}_{\alpha}$ & $0.71073 / \mathrm{MoK}_{\alpha}$ & $0.71073 / \mathrm{MoK}_{\alpha}$ \\
\hline Crystal system & Monoclinic & Monoclinic & Orthorhombic \\
\hline Space group & $P 2_{1} / n$ & $P 2_{1} / n$ & Pnma \\
\hline \multicolumn{4}{|l|}{ Unit cell dimensions } \\
\hline$a(\AA)$ & $10.7920(7)$ & $10.8764(4)$ & $16.7396(7)$ \\
\hline$b(\AA)$ & $17.3019(12)$ & $17.5580(5)$ & $22.8150(11)$ \\
\hline$c(\AA)$ & $13.2692(10)$ & $13.2732(4)$ & $14.0970(5)$ \\
\hline$\beta\left({ }^{\circ}\right)$ & $94.735(2)$ & $94.795(1)$ & 90 \\
\hline Volume, V $\left(\mathrm{nm}^{3}\right)$ & $2469.2(3)$ & $2525.88(14)$ & $62.6314(15)$ \\
\hline$Z$ & 2 & 2 & 4 \\
\hline Density calculated $\left(\mathrm{Mg} / \mathrm{m}^{3}\right)$ & 1.809 & 1.885 & 3.301 \\
\hline Absorption coefficient $\left(\mathrm{mm}^{-1}\right)$ & 7.889 & 9.188 & 20.181 \\
\hline $\mathrm{F}(000)$ & 1312 & 1384 & 4624 \\
\hline Crystal size $\left(\mathrm{mm}^{3}\right)$ & $0.169 \times 0.133 \times 0.119$ & $0.756 x 0.258 \times 0.208$ & $0.358 \times 0.113 \times 0.039$ \\
\hline Method / $\theta$ Range for data collection $\left({ }^{\circ}\right)$ & $\varphi$ and $\omega$ scans / 1.94 to 28.3 & $\varphi$ and $\omega$ scans / 2.21 to 29.6 & $\varphi$ and $\omega$ scans / 1.79 to 28.3 \\
\hline Limiting indices $(h, k, l)$ & $\begin{array}{c}-8 \leftarrow h \leftarrow 14,-22 \leftarrow k \leftarrow 23 \\
-17 \leftarrow l \leftarrow 15\end{array}$ & $\begin{array}{c}-14 \leftarrow \mathrm{h} \leftarrow 15,-20 \leftarrow \mathrm{k} \leftarrow 24, \\
-15 \leftarrow 1 \leftarrow 18\end{array}$ & $\begin{array}{c}-8 \leftarrow \mathrm{h} \leftarrow 22,-30 \leftarrow \mathrm{k} \leftarrow 28, \\
-18 \leftarrow 1 \leftarrow 18\end{array}$ \\
\hline Reflections collected & 23207 & 27118 & 32379 \\
\hline Reflections unique/ $\mathrm{R}_{\text {int }}$ & $6115\left[\mathrm{R}_{i n t}=0.0610\right]$ & $7096\left[\mathrm{R}_{i n t}=0.0269\right]$ & $6844\left[\mathrm{R}_{i n t}=0.0517\right]$ \\
\hline Completeness to theta & $28.3(99.9 \%)$ & $29.6(99.7 \%)$ & $28.3(99.7 \%)$ \\
\hline Data/restraints/parameters & $6115 / 0 / 253$ & $8357 / 0 / 343$ & $6844 / 0 / 238$ \\
\hline Absorption correction & Multi-scan & Gaussian & Gaussian \\
\hline Min. and max. transmission & 0.4512 and 0.3473 & 0.9424 and 0.4205 & 0.98757 and 0.54148 \\
\hline Refinement method & $a$ & $a$ & $a$ \\
\hline Hydrogen treatment & constr & constr & constr \\
\hline Final $R$ indices $[\mathrm{I}>2 \sigma(\mathrm{I})]$ & $\begin{array}{c}\mathrm{R}_{1}=0.0312 \\
\mathrm{wR}_{2}=0.0723\end{array}$ & $\begin{array}{c}\mathrm{R}_{1}=0.0221 \\
\mathrm{wR}_{2}=0.0439\end{array}$ & $\begin{array}{c}\mathrm{R}_{1}=0.0338 \\
\mathrm{wR}_{2}=0.0822\end{array}$ \\
\hline $\mathrm{R}$ indices (all data) & $\begin{array}{c}\mathrm{R}_{1}=0.0522 \\
\mathrm{wR}_{2}=0.0992\end{array}$ & $\begin{array}{c}\mathrm{R}_{1}=0.0311 \\
\mathrm{wR}_{2}=0.0459\end{array}$ & $\begin{array}{c}\mathrm{R}_{1}=0.0646 \\
\mathrm{wR}_{2}=0.1257\end{array}$ \\
\hline Goodness-of-fit, S & 1.078 & 1.018 & 1.160 \\
\hline Largest diff. peak and hole $\left(\mathrm{e} \AA^{-3}\right)$ & 1.230 and -1.655 & 1.728 and -0.961 & 2.297 and -1.956 \\
\hline
\end{tabular}

Table 2. Selected bond lengths $(\AA)$ and angles (degree) refined from X-ray data for $\mathbf{1}(\mathrm{X}=\mathrm{Cl})$ and $\mathbf{2}(\mathrm{X}=\mathrm{Br})$

\begin{tabular}{lcc}
\hline Bond Lengths & $\mathbf{1}$ & $\mathbf{2}$ \\
\hline $\mathrm{Hg}-\mathrm{X}$ & $2.5928(14)$ & $2.7122(3)$ \\
$\mathrm{Hg}-\mathrm{Se}$ & $2.5134(6)$ & $2.5107(3)$ \\
$\mathrm{Hg}-\mathrm{P}$ & $2.4467(12)$ & $2.4494(6)$ \\
$\mathrm{X}-\mathrm{Hg}^{\mathrm{i}}$ & $2.8978(14)$ & $3.0037(3)$ \\
\hline Bond Angles & & \\
\hline $\mathrm{P}-\mathrm{Hg}-\mathrm{Se}$ & $83.55(9)$ & $133.42(2)$ \\
$\mathrm{P}-\mathrm{Hg}-\mathrm{X}$ & $113.94(5)$ & $133.97(2)$ \\
$\mathrm{Se}-\mathrm{Hg}-\mathrm{X}$ & $109.19(4)$ & $108.34(2)$ \\
$\mathrm{Hg}-\mathrm{X}-\mathrm{Hg} \mathrm{i}^{\mathrm{i}}$ & $95.49(4)$ & $93.261(8)$ \\
$\mathrm{Se}-\mathrm{Hg}-\mathrm{X}^{\mathrm{i}}$ & $108.74(3)$ & $106.14(2)$ \\
$\mathrm{P}-\mathrm{Hg}-\mathrm{X}^{\mathrm{i}}$ & $93.53(4)$ & $95.029(2)$ \\
$\mathrm{Cl}-\mathrm{Hg}-\mathrm{X}^{\mathrm{i}}$ & $84.51(4)$ & $86.739(8)$ \\
\hline
\end{tabular}

$\left({ }^{(}\right)-\mathrm{x},-\mathrm{y},-\mathrm{z}$.
Both compounds crystallize in the monoclinic space group $P 2_{1} / n$ where the center of each molecule is located over an inversion center of this space group. In each single molecule of $\mathbf{1}$ and $\mathbf{2}$ the $\mathrm{Hg}^{2+}$ ions present a distorted tetrahedral configuration and they are linked through asymmetric $[\mu-\mathrm{X}]^{-}$bridges $(\mathrm{X}=\mathrm{Cl}(\mathbf{1}), \mathrm{Br}(\mathbf{2}))$. The distorted tetrahedral coordination of the $\mathrm{Hg}^{2+}$ ions is accomplished by one $\mathrm{PCy}_{3}$ and one $\mathrm{PhTe}^{-}$ligand.

The monomeric cluster, $\left[\mathrm{Hg}_{5} \mathrm{Br}_{3}(\mathrm{TePh})_{7}\right]$, of the compound $\mathbf{3}$, generated by the application of the symmetry of the orthorhombic space group Pnma on the asymmetric unit $\mathrm{Hg}_{3} \mathrm{Br}_{3}(\mathrm{TePh})_{4}$ (see Table 3), is displayed in Figure 3. The monomeric units assemble by connections made by four $\left[\mu_{2}-\mathrm{Te}(\mathrm{Ph})\right]^{-}$ bridges, where the $\mathrm{Te}^{\mathrm{i}}, \mathrm{Te}^{\mathrm{ii}}, \mathrm{Te}^{\mathrm{iii}}$ and $\mathrm{Te}^{\mathrm{iv}}$ atoms are the connectors into polymeric chains, which extend along 
Table 3. Selected bond lengths $(\AA)$ and angles (degree) refined from $\mathrm{X}$-ray data for $\mathbf{3}$

\begin{tabular}{|c|c|c|c|}
\hline \multicolumn{4}{|l|}{ Bond Lengths } \\
\hline $\operatorname{Hg}(1)-\operatorname{Br}(1)$ & $2.7183(8)$ & $\operatorname{Hg}(2)^{\mathrm{ii}-\mathrm{Te}}(4)^{\mathrm{ii}}$ & $2.8048(8)$ \\
\hline $\operatorname{Hg}(1)-\mathrm{Te}(3)$ & $2.7691(8)$ & $\operatorname{Hg}(2)^{\mathrm{ii}}-\operatorname{Br}(2)^{\mathrm{ii}}$ & $2.8805(12)$ \\
\hline $\operatorname{Hg}(1)-\mathrm{Te}(2)$ & $2.7740(8)$ & $\operatorname{Hg}(3)^{\mathrm{ii}}-\mathrm{Br}(3)^{\mathrm{ii}}$ & $2.6441(17)$ \\
\hline $\operatorname{Hg}(1)-\mathrm{Te}(1)$ & $2.8094(8)$ & $\operatorname{Hg}(3)^{\mathrm{ii}}-\mathrm{Te}(2)$ & $2.7109(8)$ \\
\hline $\operatorname{Hg}(2)-\mathrm{Te}(3)$ & $2.8033(8)$ & $\operatorname{Hg}(3)^{\mathrm{ii}-\mathrm{Te}}(4)^{\mathrm{ii}}$ & $3.0369(11)$ \\
\hline $\operatorname{Hg}(2)^{\mathrm{i}}-\mathrm{Te}(1)$ & $2.7360(8)$ & & \\
\hline \multicolumn{4}{|l|}{ Bond Angles } \\
\hline $\operatorname{Br}(1)-\mathrm{Hg}(1)-\mathrm{Te}(3)$ & $112.41(4)$ & $\operatorname{Br}(3)-\mathrm{Hg}(3)-\mathrm{Te}(2)^{\mathrm{i}}$ & $107.09(2)$ \\
\hline $\operatorname{Br}(1)-\mathrm{Hg}(1)-\mathrm{Te}(2)$ & $109.35(4)$ & $\mathrm{Te}(2)^{\mathrm{i}}-\mathrm{Hg}(3)-\mathrm{Te}(2)^{\mathrm{ii}}$ & $134.10(4)$ \\
\hline $\mathrm{Te}(3)-\mathrm{Hg}(1)-\mathrm{Te}(2)$ & $111.97(2)$ & $\operatorname{Br}(3)-\mathrm{Hg}(3)-\mathrm{Te}(4)$ & $104.27(5)$ \\
\hline $\operatorname{Br}(1)-\mathrm{Hg}(1)-\mathrm{Te}(1)$ & $92.57(4)$ & $\mathrm{Te}(2)^{\mathrm{i}}-\mathrm{Hg}(3)-\mathrm{Te}(4)$ & $100.13(2)$ \\
\hline $\mathrm{Te}(3)-\mathrm{Hg}(1)-\mathrm{Te}(1)$ & $113.35(2)$ & $\operatorname{Hg}(2)^{\mathrm{iii}}-\mathrm{Te}(4)-\operatorname{Hg}(2)$ & $94.25(3)$ \\
\hline $\mathrm{Te}(2)-\mathrm{Hg}(1)-\mathrm{Te}(1)$ & $115.68(3)$ & $\mathrm{Hg}(2)-\mathrm{Te}(4)-\mathrm{Hg}(3)$ & $122.62(2)$ \\
\hline $\mathrm{Te}(1)^{\mathrm{i}}-\mathrm{Hg}(2)-\mathrm{Te}(3)$ & $116.35(3)$ & $\mathrm{Hg}(1)-\mathrm{Te}(3)-\mathrm{Hg}(2)$ & $101.97(2)$ \\
\hline $\mathrm{Te}(1)^{\mathrm{i}}-\mathrm{Hg}(2)-\mathrm{Te}(4)$ & $122.39(3)$ & $\mathrm{Hg}(3)^{\mathrm{iv}}-\mathrm{Te}(2)-\mathrm{Hg}(1)$ & $100.98(3)$ \\
\hline $\mathrm{Te}(3)-\mathrm{Hg}(2)-\mathrm{Te}(4)$ & $108.28(3)$ & $\operatorname{Hg}(2)^{\mathrm{iv}}-\mathrm{Te}(1)-\mathrm{Hg}(1)$ & $96.53(2)$ \\
\hline $\mathrm{Te}(1)^{\mathrm{i}}-\mathrm{Hg}(2)-\mathrm{Br}(2)$ & $114.45(4)$ & $\operatorname{Hg}(1)-\operatorname{Br}(1)-\operatorname{Hg}(1)^{\mathrm{iii}}$ & $130.88(6)$ \\
\hline $\mathrm{Te}(3)-\mathrm{Hg}(2)-\mathrm{Br}(2)$ & $103.34(4)$ & $\operatorname{Hg}(2)-\operatorname{Br}(2)-H g(2)^{i i i}$ & $91.06(5)$ \\
\hline $\mathrm{Te}(4)-\mathrm{Hg}(2)-\mathrm{Br}(2)$ & $86.98(3)$ & & \\
\hline
\end{tabular}

(i) $\mathrm{x}-1 / 2, \mathrm{y},-\mathrm{z}+3 / 2$ (ii) $\mathrm{x}-1 / 2,-\mathrm{y}+3 / 2,-\mathrm{z}+3 / 2$ (iii) $\mathrm{x},-\mathrm{y}+3 / 2, \mathrm{z}$ (iv) $\mathrm{x}+1 / 2, \mathrm{y},-\mathrm{z}+3 / 2$.

the crystallographic axis $a$, as shown in Figure 4. This compound is very similar in structure to $\left[\mathrm{Hg}_{5} \mathrm{Cl}_{3}(\mathrm{SePh})_{7}\right]$, (4), presented in Scheme $1 .{ }^{24}$

\section{Thermogravimetric analyses}

Thermogravimetric analyses of compounds $\mathbf{1}$ and $\mathbf{2}$ in a dynamic nitrogen flow show that the thermal decomposition in the range $25-700{ }^{\circ} \mathrm{C}$ occurs in one step. The mass losses of $100 \%$ occur at 270 and $315{ }^{\circ} \mathrm{C}$ to $\mathbf{1}$ and $\mathbf{2}$, respectively, suggesting a cleavage of the cluster and sublimation of the resulting fragments. The thermogravimetric analysis of $\mathbf{3}$ displays a four-step process probably due to stepwise loss of the ligands. The observed mass loss in the first step of $20 \%$ at $192{ }^{\circ} \mathrm{C}$ agrees with the theoretical weight loss of two $(\mathrm{Ph})_{2}$ Te units $(21 \%)$. Mass losses of $47 \%$ at $269^{\circ} \mathrm{C}$ (second step) and $24 \%$ at $390{ }^{\circ} \mathrm{C}$ (third step) were also observed, which suggest the cleavage of three $\mathrm{PhTeHgBr}$ moieties (theoretical value 54\%) and sublimation of two HgTe units (theoretical value 24\%), respectively. In the fourth step, a mass loss of $6 \%$ at $520{ }^{\circ} \mathrm{C}$ occurs. After the four-step process, $4 \%$ of the residue has remained.

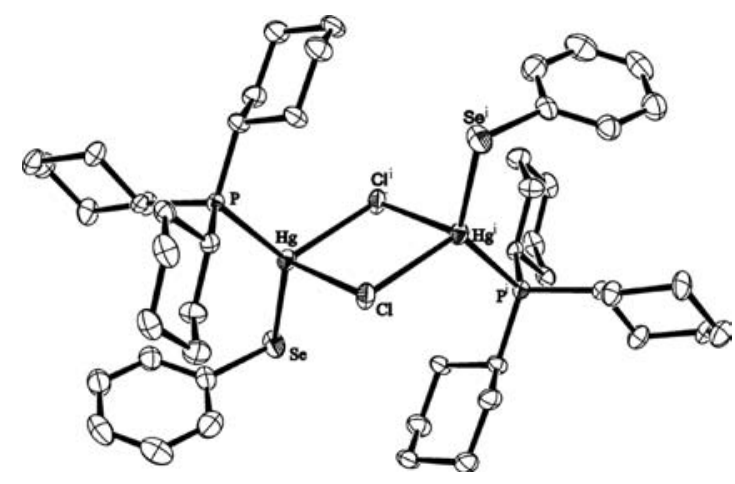

Figure 1. An ORTEP view of $\left[\mathrm{Hg}_{2} \mathrm{Cl}_{2}(\mathrm{SePh})_{2}\left(\mathrm{PCy}_{3}\right)_{2}\right]$, (1), with the thermal ellipsoids at the $50 \%$ probability level. The labelling scheme used for the phenyl and cyclohexyl rings and the hydrogen atoms is omitted for clarity. Symmetry transformation used to generate equivalent atoms: (i) $-\mathrm{x},-\mathrm{y},-\mathrm{z}$.

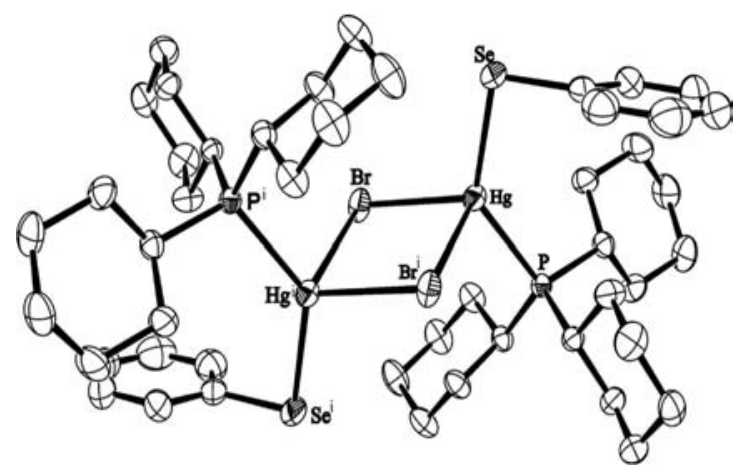

Figure 2. An ORTEP view of $\left[\mathrm{Hg}_{2} \mathrm{Br}_{2}(\mathrm{SePh})_{2}\left(\mathrm{PCy}_{3}\right)_{2}\right]$, (2), with the thermal ellipsoids at the $50 \%$ probability level. The labelling scheme used for the phenyl and cyclohexyl rings and the hydrogen atoms is omitted for clarity. Symmetry transformation used to generate equivalent atoms: (i) $-\mathrm{x},-\mathrm{y},-\mathrm{z}$.

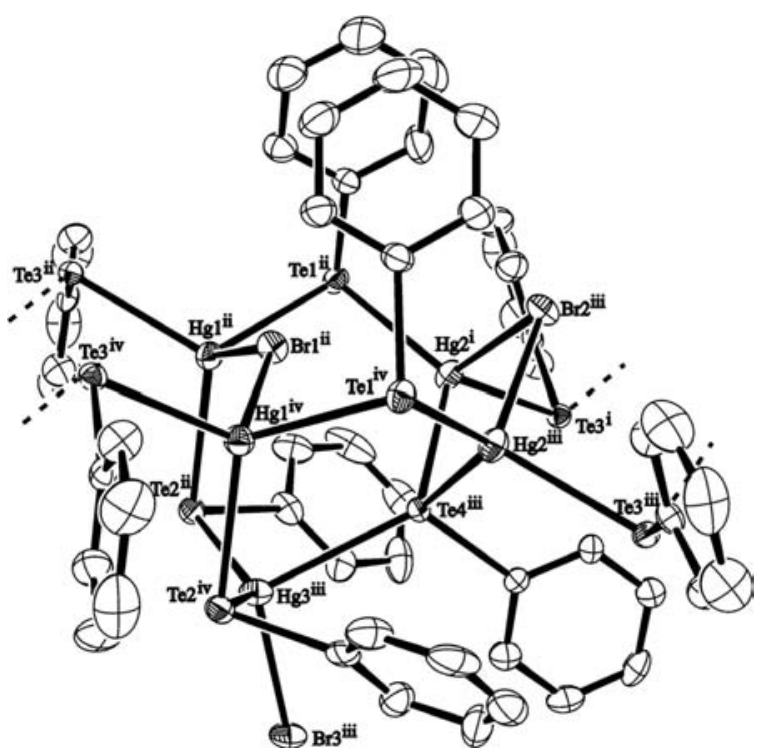

Figure 3. An ORTEP view of $\left[\left\{\mathrm{Hg}_{5} \mathrm{Br}_{3}(\mathrm{TePh})_{7}\right\}_{n}\right],(3)$, with the thermal ellipsoids at the $50 \%$ probability level. The labelling scheme used for the phenyl rings and the hydrogen atoms is omitted for clarity. Symmetry transformation used to generate equivalent atoms: (i) $\mathrm{x}, \mathrm{y}, \mathrm{z}$; (ii) $-\mathrm{x}+0.5$,

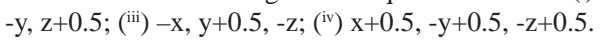




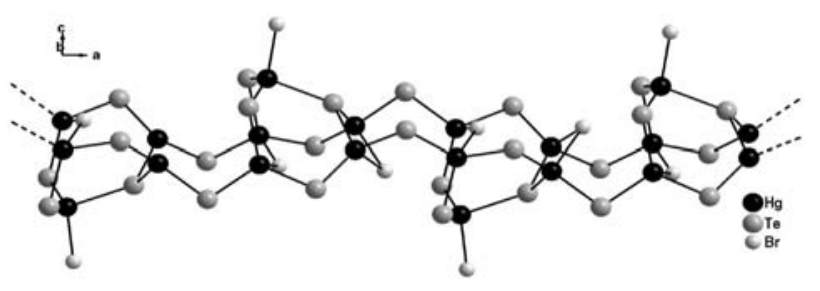

Figure 4. A polymeric assembly of $\mathbf{3}$ along the crystallographic axis $a$. The phenyl rings are omitted for clarity.

\section{Conclusions}

The experimental evidence suggests that $\mathrm{Hg}(\mathrm{EPh})_{2}$ $(\mathrm{E}=\mathrm{Se}, \mathrm{Te})$ is a valuable precursor for the preparation of small cluster molecules and nanoclusters (see Scheme 1) and represents, in principle, an alternative for many reagents used with these purposes. Since these methods in genera can also be applied to the synthons of the general formula $\mathrm{M}(\mathrm{ER})_{n}$, for which the examples with $\mathrm{M}=\mathrm{Mg}, \mathrm{Bi}, \mathrm{Ga}, \mathrm{In}$, $\mathrm{Sn}, \mathrm{Sb}, \mathrm{Zn}, \mathrm{Cd}, \mathrm{Hg}, \mathrm{Au}, \mathrm{Yb}, \mathrm{Zr}, \mathrm{Hf} ; \mathrm{E}=\mathrm{S}, \mathrm{Se}, \mathrm{Te} ; \mathrm{R}=$ aryl, alkyl, have been reported, ${ }^{22}$ we predict that a systematic methodology for the synthesis of binary and ternary clusters should be possible. ${ }^{24,32}$

The differentiated occurrence of small clusters achieving dimeric (1 and $\mathbf{2}$ ) and one-dimensional (3), polymeric chains linked through chalcogen and Hg bridges can be associated, among other factors, to a substantial increase of the reactivity, and this is often caused by significant increase in temperature. There are, however, other variables that must be considered as a whole in the growth process of clusters and nanoparticles: stoichiometric proportions of the reagents, solvent, time of reaction, temperature, and the presence (or not) of secondary ligands, seem all to be factors which can affect the growth of the compounds, i.e., whether small or bulk, polycyclic clusters will be the final products.

We have also observed a close similarity in the growth of binary/ternary ME/MM'E nanoclusters with some processes described in the growth of nanoparticles in general. ${ }^{35,36}$ The nucleation (growth of the particles) and the well known "Ostwald ripening" (or maturation) seem to be, ${ }^{37}$ in our case, also dependent on the concentration of the reagents and of the time. We have also noted that all the factors which are able to promote the efficient dissociation of the reagents (solvent polarity, for example), together with a resourceful nucleation (enough time of the particles in solution) should lead to the formation of clusters of higher nuclearity. Presently, we are improving experimental attempts to control the dissociation/association of particles (fragments) in solution, before their crystallization.

\section{Supplementary Information}

CCDC 745061, 745062 and 745553 contain the supplementary crystallographic data for $\mathbf{1}, \mathbf{2}$ and $\mathbf{3}$, respectively. These data can be obtained free of charge via http://www.ccdc.cam.ac.uk/conts/retrieving.html, or from the Cambridge Crystallographic Data Centre, 12 Union Road, Cambridge CB2 1EZ, UK; fax: (44) 1223-336-033; or e-mail: deposit@ccdc.cam.ac.uk.

TGA measurements data for $\mathbf{1}, \mathbf{2}$ and $\mathbf{3}$ are available free of charge at http://jbcs.sbq.org.br, as PDF file.

\section{Acknowledgments}

This work was supported with funds from MCT/CNPq 15/2007 - Universal (Proc. No. 472509/2007-1). The author (B. T.) thanks CNPq for a scholarship.

\section{References}

1. Tran, D. T. T.; Beltran, L. M. C.; Kowalchuk, C. M.; Trefiak, N. R.; J. Taylor, N. J.; Corrigan, J. F.; Inorg. Chem. 2002, 41, 5693.

2. De Groot, M. W.; J. Taylor, N. J.; Corrigan, J. F.; Inorg. Chem. 2005, 44, 5447.

3. Henkel, G.; Krebs, B.; Chem. Rev. 2004, 104, 801.

4. Li, H.; Kim, J.; Groy, T. L.; O’Keeffe, M.; Yaghi, O. M.; J. Am. Chem. Soc. 2001, 123, 4867.

5. Wang, C.; Bu, X.; Zheng, N.; Feng, P.; J. Am. Chem. Soc. 2002, 124, 10268.

6. Feng, P.; Bu, X.; Zheng, N.; Acc. Chem. Res. 2005, 38, 293.

7. Zhang,Q.; Bu, X.; Han, L.; Feng, P.; Inorg. Chem. 2006, 45 , 6684.

8. Wang, C.; Bu, X.; Zheng, N.; Feng, P.; J. Am. Chem. Soc. 2007, 129,8412 .

9. Vossmeyer, T.; Reck, G.; Katsikas, L.; Haupt, E. T. K.; Schulz, B.; Weller, H.; Science 1995, 267, 1476.

10. Vossmeyer, T.; Reck, G.; Schulz, B.; Katsikas, L.; Weller, H.; J. Am. Chem. Soc. 1995, 117, 12881.

11. Rogach, A.; Kershaw, S.; Burt, M.; Harrison, M.; Eychmüller, A.; Weller, H.; Adv. Mater. 1999, 11, 552.

12. Eichhöfer, A.; Deglmann, P.; Eur. J. Inorg. Chem. 2004, 349.

13. Steigerwald, M. L.; Polyhedron 1994, 13, 1245.

14. Steigerwald, M. L.; Siegrist, T.; S. Stuczynski, M.; Inorg. Chem. 1991, 30, 4940.

15. Brennan, J. G.; Siegrist, T.; Stuczynski, S. M.; Steigerwald, M. L.; J. Am. Chem. Soc. 1990, 112, 9233.

16. Brennan, J. G.; Siegrist, T.; Stuczynski, S. M.; Steigerwald, M. L.; J. Am. Chem. Soc. 1989, 111, 9240. 
17. Corrigan J. F.; Fenske, D.; Angew. Chem., Int. Ed. Engl. 1997, 36, 1981.

18. Bettenhausen, M.; Eichöfer, A.; Fenske, D.; Semmelmann, M. Z.; Z. Anorg. Allg. Chem. 1999, 625, 593.

19. Zhu, N.; Fenske, D.; J. Chem. Soc., Dalton Trans. 1999, 1067.

20. Fenske, D.; Zhu, N.; Langetepe, T.; Angew. Chem., Int. Ed. Engl. 1998, 37, 2640.

21. Eichhöfer, A.; Tröster, E.; Eur. J. Inorg. Chem. 2002, 2253.

22. Sadekov, I. D.; Zakharov, A. V.; Russ. Chem. Rev. 1999, 68, 909.

23. Lang, E. S. ; Burrow, R. A.; Stieler, R.; Villetti, M. A.; J. Organomet. Chem. 2009, 694, 3039.

24. Lang, E. S.; de Oliveira, G. N. M.; Tirloni, B.; Lago, A. B.; Vázquez-López, E. M.; J. Clust. Sci. 2009, 20, 467.

25. Lang, E. S.; Zan, R.A.; Gatto, C.C.; Burrow, R.A.; VázquezLópez, E. M.; Eur. J. Inorg. Chem. 2002, $2,331$.

26. Lang, E. S.; de Oliveira, G. M.; Dias, M. M.; Santos, S. S.; Abram, U.; Vázquez-López, E. M.; Z. Anorg. Allg. Chem. 2004, 630, 462.

27. Casagrande, G. A.; Lang, E. S.; de Oliveira, G. M.; Hörner, M.; Broch, F.; Inorg. Chim. Acta 2007, 360, 1776.
28. Lang, E. S.; Tirloni, B.; de Oliveira, G. N. M.; Villetti, M. A.; Inorg. Chim. Acta 2009, 362, 3114.

29. Lang, E. S.; de Oliveira, G. N. M.; Tirloni, B.; Villetti, M. A.; J. Clust. Sci. 2008, 19, 459.

30. Lang, E. S.; Peppe, C.; Zan, R.A.; Abram, U.; Vázquez-López, E. M.; Krumm, B.; Ruscitti, O. P.; Z. Anorg. Allg. Chem. 2002, $628,2815$.

31. Lang, E. S.; de Oliveira, G. M.; Back, D. F.; Santos, S. S.; Z. Anorg. Allg. Chem. 2004, 630, 730.

32. Back, D. F.; de Oliveira, G. N. M.; Burrow, R. A.; Castellano, E. E.; Abram, U.; Lang, E. S.; Inorg. Chem. 2007, 46, 2356.

33. Back, D. F.; de Oliveira, G. N. M.; Lang, E. S.; Polyhedron 2008, 27, 3255.

34. Sheldrick, G. M.; Acta Cryst. 2008, A64, 112.

35. Murray, C. B.; Kagan, C. R.; Bawendi M. G.; Annu. Rev. Mater. Sci. 2000, 30, 545.

36. Cushing, B. L.; Kolesnichenko, V. L.; O’Connor, C. J.; Chem. Rev. 2004, 104, 3893.

37. Ostwald, W. In Lehrbuch der Allgemeinen Chemie, Kohlhammer, W., ed.; Verlag GmbH: Stuttgart, Germany, 1896.

Received: September 12, 2009 Web Release Date: March 22, 2010 


\title{
Synthesis and Crystal Structure of Chalcogenide Cluster Compound
}

\author{
Bárbara Tirloni, ${ }^{a}$ Davi F. Back, ${ }^{a}$ Robert A. Burrow, ${ }^{a}$ Gelson N. M. de Oliveira, ${ }^{a}$ \\ Marcos A. Villetti ${ }^{b}$ and Ernesto S. Lang* $*$, \\ ${ }^{a}$ Departamento de Química, Universidade Federal de Santa Maria, \\ 97105-900, Santa Maria - RS, Brazil \\ ${ }^{b}$ Departamento de Física, Universidade Federal de Santa Maria, \\ 97105-900, Santa Maria - RS, Brazil
}

Thermogravimetrical measurements

Thermogravimetric measurements were carried out on a Shimadzu DTG-60 device. The experiments were performed in the temperature range from 25 to $700{ }^{\circ} \mathrm{C}$ at heating rates of $10^{\circ} \mathrm{C} \mathrm{min}^{-1}$ on each sample. The average sample size was 10

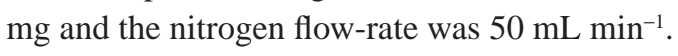

\section{DrTG}

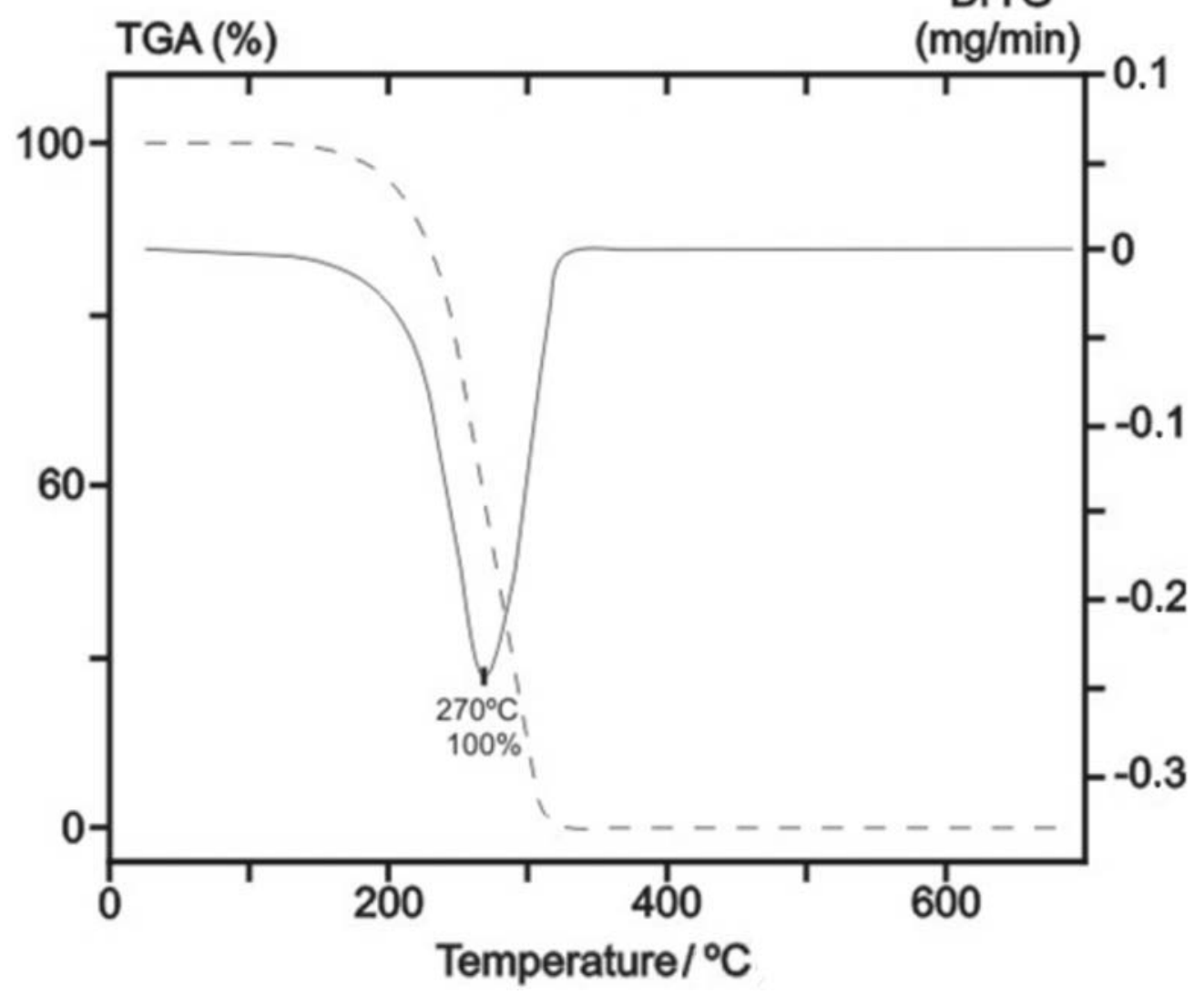

Figure S1. TGA of $\left[\mathrm{Hg}_{2} \mathrm{Cl}_{2}(\mathrm{SePh})_{2}\left(\mathrm{PCy}_{3}\right)_{2}\right],(\mathbf{1})$. 


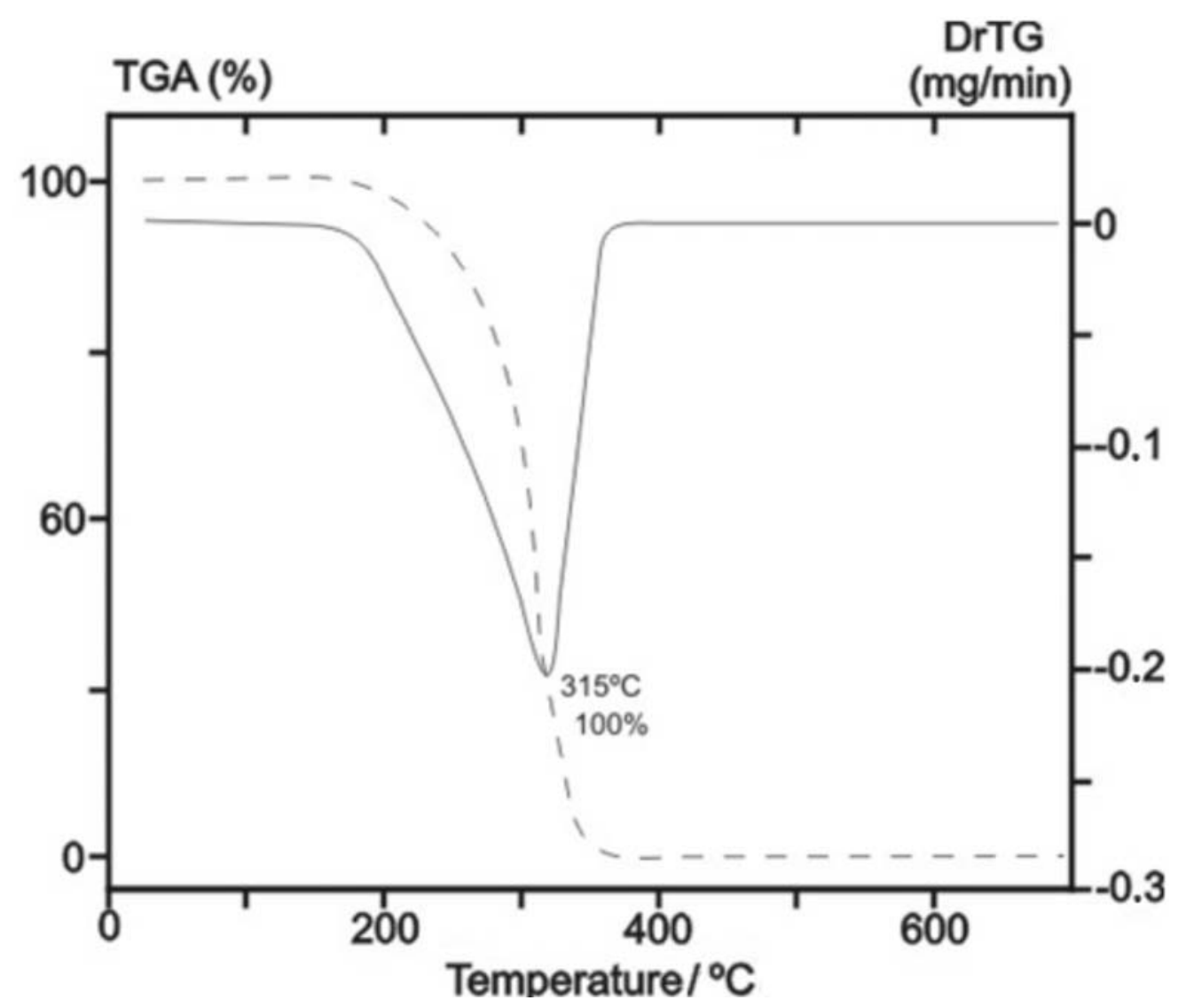

Figure 2. TGA of $\left[\mathrm{Hg}_{2} \mathrm{Br}_{2}(\mathrm{SePh})_{2}\left(\mathrm{PCy}_{3}\right)_{2}\right]$, (2).

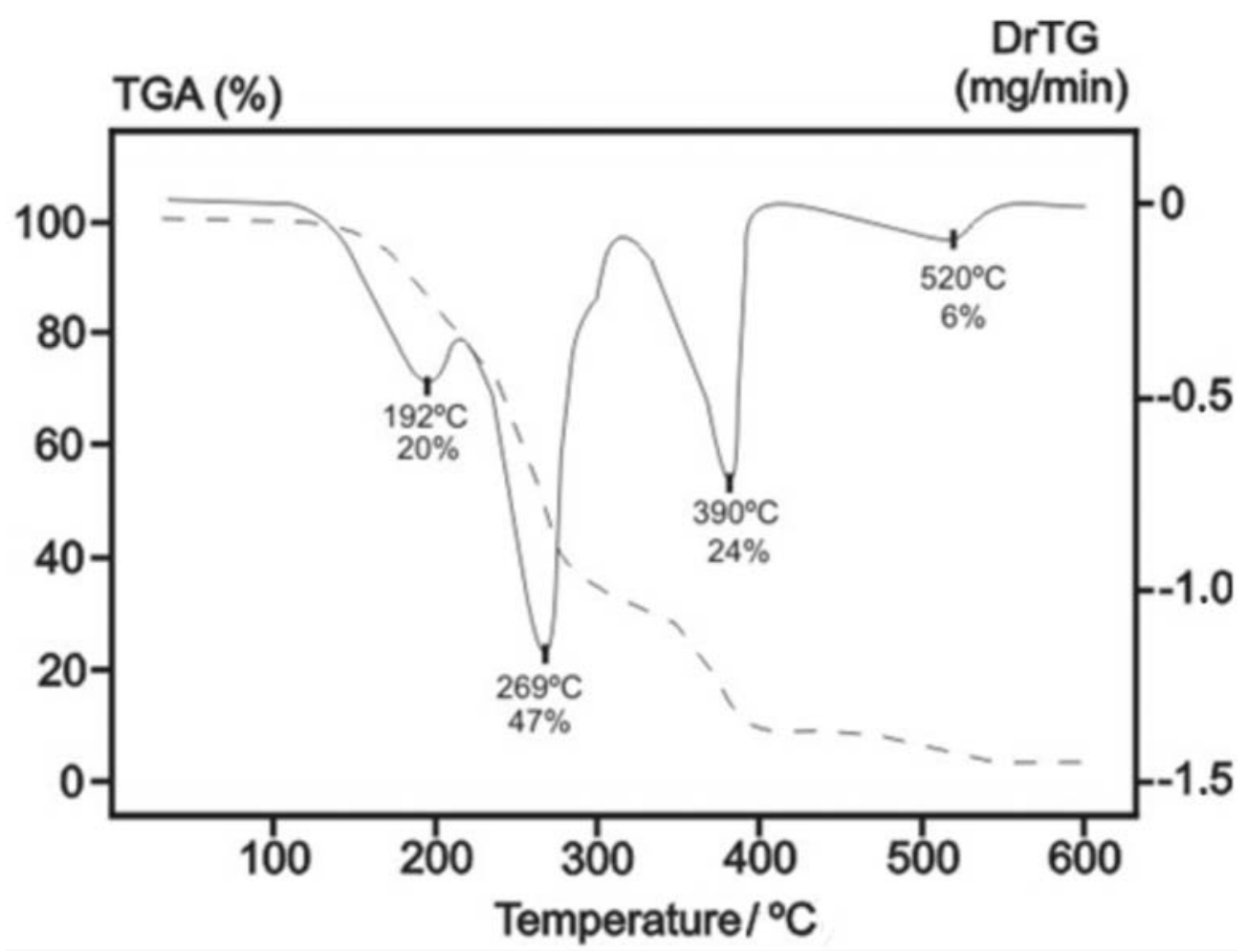

Figure 3. TGA of $\left[\left\{\mathrm{Hg}_{5} \mathrm{Br}_{3}(\mathrm{TePh})_{7}\right\}_{n}\right],(\mathbf{3})$. 